\title{
Commodity Derivative Markets in India: An Evolving Paradigm
}

\author{
Sarika Rachuri ${ }^{1}$, Dr. Rajinder Aurora ${ }^{2}$ \\ ${ }^{1}$ Faculty in Economics, IBS Business School, Mumbai \\ ${ }^{2}$,Professor in Finance, IBS Business School, Mumbai
}

\begin{abstract}
Recent moves by the World Bank to design market-based approaches for dealing with commodity price risk provide a new and urgent push for research and design in the area of commodity futures markets as a policy option. Since the breakdown of the International Commodity Agreements, there has been little progress in finding a solution to the problem of price risk emanating from price volatility. This paper aims to provide a background to the more general issue of development and growth in less developed countries (LDCs) by examining past and current policy prescriptiions to reduce the effects of price volatility and mitigating risk in primary commodity markets. Also, commodity exchanges are an evolving market undergoing a dramatic paradigm shift. This paper seeks to trace out the evolution of Indian commodity exchanges. It looks at whether the Indian commodity exchanges have been impacted in terms of their hedging efficiency after a couple of jolts inflicted on them due to commodity transaction tax (CTT), and the NSEL scam.
\end{abstract}

Keywords: Derivatives Hedging, Price risk Management, Commodity Exchanges, CTT

\section{Introduction}

Commodity Derivative markets have played a pivotal role in strengthening the agricultural and nonagricultural economy. This component of the value chain of the business is susceptible to volatile price movements of different commodities. Commodity derivatives have played an instrumental role in providing a platform for hedging for farmers, producers, and other players in the value chain. Across the world, commodity exchanges have been providing various products and platforms that perform two important functions:

- Price Discovery

- Hedging

In recent years, concomitant with the rise in commodity prices, there has been "financialisation of commodities". Commodities' has been viewed as a distinct asset class and has been used as a portfolio diversifier. Hence commodity exchanges and derivatives throughout the world have provided instruments for risk mitigation and a source of alternative yield.

The story in India is however different. Like in the western world, commodity exchanges in India too have their hallowed origins and are as old as CBOT (Chicago Board Of Trade). However, rather than being used as platforms for mitigating risks, they have been perceived as dens of speculation and sources for fuelling inflation. They have remained as a missing link in the chessboard of the commodity space.

Only in the last decade with liberalization, the commodity derivatives have been revived. While tracing the history of commodity exchanges in India, this paper brings out the issues and challenges that have stalled the growth of commodity markets, and seeks to examine whether the regulatory reforms in commodity markets have enabled the exchanges to emerge as platforms for risk mitigation and price discovery. 


\subsection{Literature Review}

The commodity exchanges have their origins in Japan in 1697,(Baakken 1966). Rice was a staple crop and played a catalytic role in development of the Japanese economy. A large number of farmers, samurai, and feudal class used rice as a means of payment. This led to development of rice tickets. The growth of rice brokers, and farmers led to the evolution of a rice exchange in Osaka called Dojma rice exchange which was institutionalised in 1730 .

Around the world the invention of railroads, telegraph and development 0f other infrastructure was changing the demand supply dynamics of the agriculture market. Baffes (2011). The increase in speed of information and movement of grains severely impacted price dynamics.

Biswa Saha (2011) points out how the largest commodity exchange CBOT (Chicago Board of Trade) was formed on account of these developments. The invention of railroads and telegraph made Chicago a commercial hub for the farmers of the Midwest who came to sell their wheat. It provided a central place to deal in wheat. This led to evolution of wheat futures, by standardising a grain contract. The innovations in weighing, grading, and standardisation, made wheat produce of farmers fungible. Nearly five commodity exchanges were established in the world by the end of the 1800s. India too boasts of a glorious past in commodity exchanges. The cotton trader association in 1875 set up India's first organised Cotton exchange. Later, India saw flourishing of different commodity exchanges like wheat in Hapur (1913), and oilseeds in Gujarat (1900).

\subsection{Functions of Commodity Exchanges}

A lot of empirical research has been undertaken to find out the role and functions of commodity markets. Unlike other subsets of the financial market like equities or bonds, commodity derivative markets play a distinctive role. The two critical roles that commodity exchanges play are:-

Price Discovery

Price Risk Management

This segment by far helps in infusing price stability by offering instruments to different stake holders to insulate them against volatile price movements. Both the functions are critical and are inter-twined with one another.

At every stage of the value chain, stakeholders face information asymmetry and face either an upside or down side risk due to price volatility. By bringing a large number of buyers and sellers on the commodity exchanges together, who invest in commodity derivatives, a reference price emerges (Pavaskar et all 2010). The future markets disseminate information more swiftly than the spot market and hence become a true forecaster of spot prices.

Large empirical literature exists showing correlation of spot and future prices Garbade Silber (1983) for many commodities. This research was carried out further by Quan (1992) among many others. The prices so discovered in futures markets can be factored in by the players in taking business decisions which in turn helps in reducing risks.

Commodity exchanges offer instruments like futures and options that make effective tools for hedging. Hedging enables market participants to take an equal and opposite position in futures market vis-a-vis the spot market to compensate and offset the spot position against any loss. The loss or profit in the spot market is exactly off-set by the hedge position in the futures market. The prise risk arising in the cash (spot) market is offset by using futures and serves as a hedging tool. If these tools result in an exact offset then they form a perfect hedge. Hence a lot of research work has been undertaken to measure and define the hedging effectiveness (Edirington 1979, Rolfo 1980).

The litmus test of efficacy of a commodity exchange and success of future contracts depends on their hedging effectiveness (Silber 1985). Hence many mathematical models have been developed which consider optimal hedging models (Berg 1985) and have been used to test the efficacy of European exchanges.

Pennings (2003) has done a detailed literature review of how the role of futures market has been an evolving paradigm. The paper brings out various perspectives of the futures market - insurance perspective, arbitrage perspective, portfolio perspective, and the current institutional perspective, which shows that the role of commodity exchanges has been fast evolving.

Although the fundamental role of commodities is to protect the participants against adverse price movement, however in recent years commodities has been viewed as a distinct asset class. The huge costs in terms of storage made it difficult to invest in commodities. However, commodity derivatives are now seen and 
used as investments in the portfolio. Gortorn and Rouwenhurst (2004) have stated the benefits of investing in commodities. Chief among them are that they are a good hedge against inflation, and they offer portfolio diversification benefits. Research on the portfolio diversification benefits of commodities found that the risk adjusted returns are better for portfolios which have commodities, taking the period from 2000-2008. It has examined how financialisation of commodities has coincided with the commodity super cycle (Pavaskar and Rachuri 2010).

\subsection{Role of commodity exchanges in India:}

Commodity exchanges in India have had a glorious past. India's first commodity exchange, the Bombay Cotton Exchange, was established in 1893, and was often compared to the Chicago Board of Trade. As mentioned earlier, the pre-independence era in India saw flourishing of commodity exchanges. A large number of exchanges were set up in different parts of the country. Commodity derivatives enjoyed unbridled growth till the outbreak of the Second World War. It was after independence that Indian commodity exchanges saw a ban in commodity trading. Barring this episode, commodity markets were a great forum for price discovery and hedging, and they included the presence of overseas players too.

Post the Second World War as India gained independence, it was decided that commodity exchanges be brought under the regulatory ambit. Consequently legislative changes were enacted and Forward Contract (Regulations) Act (FCRA) was established in 1949. The FCRA mandated that commodity exchanges be brought under the supervision of a regulator and Forward Market Commission was setup as a regulator to oversee their functions. However despite policy impetus, the commodity exchanges in India did not thrive. The economic policies drafted under the influence of socialism did not allow these commodity exchanges to grow. Food shortages and inflationary pressures created apprehension about the alleged role these exchanges were playing in exacerbating them. Commodities markets were seen as a haven for speculation, rather than an efficient platform for price discovery or hedging. Starting in the mid-60s, the government imposed a ban on futures trading of individual commodities, blaming such activity for fomenting inflationary conditions.(Rachuri 2015). Hence by the seventies, these commodity exchanges withered away.

Economic reforms and liberalisation policies in the early nineties, with a special thrust on capital markets, led to rethinking on the role of commodity exchanges in the goods market. Under the aegis of the "Kabra Committee" in the mid-nineties, commodity exchanges were resurrected. By 2003, the ban on commodity futures was lifted. 2003 saw the establishment of the National Commodity and Derivatives Exchange (NCDEX), Multi Commodity Exchange (MCX), and other exchanges. Unlike their predecessors, these exchanges were modern automated exchanges, with screen based trading, having better settlement and risk practices, and good liquidity. These reforms coincided with an upturn in the commodity super cycle, and commodity exchanges started prospering. Over the years, there was a surge in the number of contracts traded, and volumes, and seeing this, more exchanges jumped into the fray. For instance in 2003, the total commodity traded volume in all exchanges was USD 29 billion, which jumped to USD 3,330 billion in 2013. Indian commodity exchanges have grown to global standards with MCX being ranked as the world's number 3 commodity exchange, though globally, MCX is No. 1 in Gold and Silver, No. 2 in Natural gas and No. 3 in Crude Oil.

The commodity futures were strengthened by introduction of spot markets too. It was also imperative since the price of the futures contract had to converge to the spot prices on the contract settlement date, for which a robust, transparent, and trustworthy spot market was needed. As exchanges were growing, stakeholders were pushing for legislative amendments in FCRA, greater autonomy to their regulator (FMC), introduction of more products and players in market.

Two major events that gave a significant jolt to the commodity derivative markets were:-

Introduction of CTT, and

NSEL scam

CTT or Commodity Transaction Tax is a tax similar to the Securities Transaction Tax (STT) that is levied on equity capital markets in India. The concept of CTT was first introduced in the Union Budget 2008-09 whereby the Government proposed to impose a commodities transaction tax (CTT) of $0.017 \%$, equivalent to the rate of equity futures at that point of time. However, it was withdrawn subsequently as the Indian commodity market was judged to be at a very nascent stage. Imposition of such a transaction tax would have adversely affected the growth of organized commodity derivatives markets in India, at that point in time. Nevertheless, in the Union Budget 2013-14 CTT was re-introduced. However, it was made applicable only for non-agricultural 
commodity futures at the rate of $0.01 \%$, which was equivalent to the rate of equity futures. The levy of CTT was cast on non-agricultural commodities. Along with this, transactions in commodity derivatives were declared to be made non-speculative, and hence for traders in the commodity derivative segment, any losses arising from such transactions could be set off against income from other sources; very similar to the provisions applicable for the securities market transactions. A separate provision for CTT has been made in the Finance Act, 2013 (Chapter VII). The introduction of CTT had a negative impact on the volumes of commodity derivatives trading. National Spot Exchange limited (NSEL) was the country's premier commodity spot exchange. In 2013, it got mired into a controversy. By a quirk of legalese, technically NSEL was not under the purview of any regulator, as the FMC governed only the forwards market. On account of this regulatory vacuum the exchange is alleged to have played fast and loose for business considerations. Conflicts of interest and absence of Chinese walls between departments led to a situation where very short term derivatives contracts were not fully backed by the underlying asset in warehouses. It was also flogging unapproved very short term futures contracts that literally offered guaranteed returns to the broker-customers who bought the contracts. This led to a default of Rs. 5600 crores (around US $\$ 0.95$ billion). In effect, NSEL failed to perform an exchange's primary function of guaranteed settlement. It was caught out, and after 31 July 2013, NSEL failed to pay the counterparties in commodity pair contracts. About 13,000 investors (counterparties) from India lost about Rs. 5600 crores when the fraud was discovered. Nor could NSEL recover money by selling goods put in warehouses by sellers, as the value of the stock was far lower than the value of the contracts. Caught in a bind, it was found that NSEL had neither the money nor the stocks to pay the buyers of commodities for future delivery, back.

Structured pair trades in commodities were the primary tool used to create this whole Ponzi like scheme. The pair trades in various commodities that were offered in one-day forward contracts of $T+2$ ( 2 days ahead of the day of the contract) and $\mathrm{T}+25$ ( 25 days ahead of the day of the contract) sometimes even $\mathrm{T}+35$ day trade payment terms contracts i.e. transactions where commodities were bought and sold at the same time, to be reversed after 25 or 35 days at a pre-determined price. Such pair trades offered an arbitrage opportunity of about $12-15 \%$ return per annum.

The Forwards Market Regulator, FMC could not fathom the fraudulent practices and was slow to react. In July 2013, it asked NSEL to stop all trades extending beyond 11 days settlement, which according to FMC, were illegal. This whole Ponzi like scheme was built up on rotating, renewing, and increasing contracts. Once this was stopped by FMC, everything fell apart. It resulted in less interest from investors in renewing their contracts and the wheel of roll-over trades came to a halt as NSEL could not raise fresh investor funds to pay old investors whose funds were maturing.

This scam had far reaching implications on the commodity derivatives market. Some of the impacts of the scam were:-

It prevented the growth of Commodity markets

Investor confidence was badly shaken

Raised questions about the efficacy of the regulation of commodity exchanges.

A strong need to put proper mechanisms in place.

It discouraged small investors from participating in derivative products.

In a desperate attempt at salvage, the policy makers decided to change the regulator for commodity derivative markets. In September 2015, FMC was folded into SEBI, and commodity derivatives markets are now under the purview of SEBI.

At the outset, it is interesting to investigate whether these incidents impaired the functioning of commodity derivative markets. A litmus test of finding the efficiency of a commodity exchange is to examine the hedging effectiveness of an exchange

An empirical study (Ghosh, Dey, Moulvi,Jain, Sinha and Rachuri 2013) has tested hedging efficiency of commodity exchanges in their most fundamental function, namely, their ability to both generate and reflect price signals to the spot market. The study uses regression methods to find out hedging efficiency.

According to this theory, It involves consideration of coefficient of

\subsection{Objectives of Research}

This paper seeks to trace out the evolution of Indian commodity exchanges. It looks at whether the Indian commodity exchanges have been impacted in terms of their hedging efficiency after the jolts inflicted on them due to commodity transaction tax (CTT), and the NSEL scam. 


\subsection{Research Methodology}

In order to test the hedging efficiency, daily price time series data of generic contracts of liquid commodities - Gold, and Crude Palm Oil (CPO), have been obtained from MCX. These commodities also represent the commodity group of precious metals, and agriculture, respectively. These commodities are from each of the groups that have good liquidity and are important from a hedger's perspective.

TABLE I: Selected commodities and their futures contracts at exchanges

\begin{tabular}{|l|l|}
\hline Commodities & Future Contracts at Exchanges \\
\hline Gold & MCX 1 Kg generic, \\
\hline Crude Palm Oil & MCX 10M T generic \\
\hline
\end{tabular}

For both the commodities we have divided time series regression into three time periods:-

Before the NSEL Scam - January 2012 to July 2013

After the Scam - August 2013 to September 2014

Removal of FMC as a Regulator and emergence of SEBI as the new regulator - October 2015 to October 2016

The daily future prices for the nearest month contract have been taken for these time periods. Similar data on spot prices have been taken and regression has been applied considering entire period as in sample data. Among all the methods, the most widely used method is using ordinary least squares estimator (OLS). To estimate hedging efficiency changes in spot prices are regressed on changes in futures prices. The hedging efficiency is represented by R-square value of the regression equation. The results have been obtained after taking into account a number of assumptions such as - the series is stationary, there is no auto correlation between residuals, and we do not consider covariance between spot and futures returns.

Results
\begin{tabular}{|l|l|l|l|}
\hline Commodities & Period & $\begin{array}{l}\text { Regression } \\
\text { coefficient }\end{array}$ & $\begin{array}{l}\text { Hedging } \\
\text { Efficiency } \\
\text { (R-square })\end{array}$ \\
\hline Gold & Jan 2012- July 2013 & 1.001 & 0.73 \\
\hline Crude Palm Oil & Jan 2012- July 2014 & 0.81 & 0.79 \\
\hline Gold & Aug 2013-Sept 2015 & 0.8 & 0.62 \\
\hline Crude Palm Oil & Aug2013-Sept 2015 & 0.72 & 0.56 \\
\hline Gold & Oct 2015-Oct 2016 & 0.75 & 0.65 \\
\hline Crude Palm Oil & Oct2015- Octr2016 & 0.67 & 0.56 \\
\hline
\end{tabular}

The efficaciousness of the Indian commodity exchange was much better for the first period before the commodity exchange got mired into controversy. Both, for gold and crude palm oil, the value of Rsquare was much higher. However post the NSEL scam, the efficacy of the exchange perhaps got impaired since the R-square value drastically reduced showing a reduction in hedging effectiveness. The last period (2015-2016) also saw a significant downturn in the entire commodity complex. This period also coincided with SEBI taking over as the new regulator, which initially created scepticism in the market.

\section{Limitations}

The time series data is based on lot of assumptions. The series is assumed to be stationary. ADF should have been conducted for better results. 


\section{Conclusions}

This paper has traced out the significance of commodity derivative markets in both developed and developing countries. For Indian commodity exchanges, it delves deeper into the reasons for their chequered growth and lays emphasis on how these commodity exchanges have evolved as platforms for hedging and price discovery. The paper looks into two important commodities - gold and crude palm oil, and concludes that prior to 2013, the policy impetus for this sector had a positive bearing on these exchanges. The regression results with a higher R-square for both commodities shows that this exchange was a great platform for hedging. However, post 2013, as the exchange got mired in controversy, the hedging effectiveness somewhat reduced. However, this cannot be conclusively deduced, since other factors such as a downturn in the commodity complex, and CTT, which could have distorted the results. Further research needs to be carried out for other metals, agricultural products, and the energy complex. After a change of regulator, SEBI is playing a proactive role in developing the commodity exchanges. The policy push for an in principle introduction of options, and bringing more players on board would definitely add liquidity and improve the efficiency of the exchanges.

\section{References}

[1] www.arthapedia.in- Commodities Transaction Tax referred on October 31, 2016 at.12.35 a.m. https://doi.org/10.1093/erae/14.1.91

[2] BERG, E. (1987): A Sequential Decision Model to Determine Optimal Farm-Level Grain Marketing Policies. In: European Review of Agricultural Economics 14 (1): 91-116.

[3] Garbade, K. D., \& Silber, W. L., 1983. Price Movement and Price Discovery in Futures and Cash Markets. Review of Economics and Statistics, 65, $289-297$ https://doi.org/10.2307/1924495

[4] Garbade, K.D., and Silver, W.L., 1979, "Dominant Satellite Relationship between Live Cattle Cash and Future Markets", The Journal of Future Markets, Vol.10, pp. 123-136.

[5] Gorton Gary B, Rouwenhorest Geert K (2005), Facts and Fantasies about Commodity Futures, SSRN.com

[6] Johnson, L. (1960), The theory of hedging and speculation in Commodity Futures, Review of Economic Studies, 27 , $139-151$ https://doi.org/10.2307/2296076

[7] Pennings, J.M.E, \& Meulenberg, M.T.G (1997), Hedging efficiency: a futures exchange management approach. Journal of futures markets , 17, $599-615$ https://doi.org/10.1002/(SICI)1096-9934(199708)17:5<599::AID-FUT5>3.0.CO;2-A

[8] Saha, B. (2011): 'An Institutional Reading of the very early history of Chicago Board of Trade: What it means for what we need to study about Indian futures market', in Commodity Vision, Vol.5, Issue 2, pp. 56-62

[9] Quan, J., 1992. "Two Step Testing Procedure for Price Discovery Role of Futures Prices". The Journal of Futures Markets, 12, 139-149.

https://doi.org/10.1002/fut.3990120203

[10] (10)http://farmdoc.illinois.edu/irwin/archive/books/Futures_Seminar_V3/Futures \%20Seminar\%20V3_Bakken.pdf

[11] (11)http://asia.nikkei.com/Viewpoints/Viewpoints/Sarika-Rachuri-India-must-press-on-with-commodities-tradingchanges

[12] (12)www.researchgate.net/profile/Nilanjan_Ghosh_PhD/publication/256542727_Hedging_EfficiencyMeasures_and _Empirical_Study/links 